\title{
Nutritional Formulation and Analysis, and Organoleptic Tests of Functional Chocolate Biscuits "Morisoya" -Supplementation of Moringa Leaves (Moringa oleifera L.) AND Soybeans (Glycine max (L.) Merill)
}

\author{
Amalia Purnamasari Zainal, Ririen Hardani and Amelia Rumi*
}

\author{
Department of Pharmacy, Faculty of Mathematics and Natural Sciences, Tadulako University, Palu City, \\ Central Sulawesi, Indonesia
}

\begin{abstract}
Moringa (Moringa oleifera) and soybeans (Glycine max) are the kinds of crops that have been known widely to the public. They both can potentially be a source of additional nutritional supplements in a variety of processed snacks, such as biscuits. This study aimed to determine the ratio of formulas in making biscuits from moringa leaf extracts and soybean extracts and the nutritional content of biscuits "Morisoya", and to conduct an organoleptic test with supplementation of moringa leaf extracts and soybean extracts. It employed a completely randomized design (CRD), consisting of nine treatments and two replications. The variables observed included: (a) protein content of chocolate biscuits "Morisoya", (b) carbohydrate content of chocolate biscuits "Morisoya", (c) fat content of chocolate biscuits "Morisoya", and (d) organoleptic/hedonic test on biscuits "Morisoya". The results show that the highest protein content is found in the treatment P8 (32.50\%), but it is not significantly different from that found in treatments P9 (31.68\%) and P7 $(29.67 \%)$, followed by the treatment P6 $(28.61 \%)$, which are not significantly different from that in the treatment P5 $(26.46 \%)$. The highest carbohydrate content is found in the treatment P1 $(62.70 \%)$ while the highest fat content is found in the treatment P9 $(28.92 \%)$. The highest result for the organoleptic/hedonic test (on a scale of 0 to 5 ) is generated by the treatment P6 (3.28), with the highest percentage of 13\% compared to the control treatment and other treatments. Based on results of the analysis on protein, carbohydrate, and fat contents as well as results of the organoleptic test, it is apparent that the treatment P6 constitutes the formula for biscuits "Morisoya" which was then selected to be developed in further research as functional biscuits.
\end{abstract}

Keywords: Functional biscuits, Moringa leaves, Formulation, Nutrition, Soybeans.

\section{INTRODUCTION}

Moringa (Moringa oleifera) has been widely known in Indonesia, especially in rural areas, but its usage is not maximized. In Indonesia, moringa trees are widely planted as a living fence and are also known as medicinal plants by utilizing all their parts, from leaves, barks, seeds, and roots [9]. According to the research conducted by Toripah et al. [11], Moringa (Moringa oliefera Lam) is a plant that contains flavonoids, saponins cytokines, and caffeoylquinic acids, and contains unsaturated fatty acids such as linoleic (omega 6) and alpha linolenic (omega 3). In addition, the leaves are also rich in micronutrients such as $\beta$ carotene, zinc ( $\mathrm{Zn})$, manganese (Mn), and iron (Fe) [1]. Considering the many nutrients contained in moringa leves, moringa leaves can potentially serve as a source of nutrition for human consumption. According to the previous research, moringa can potentially be used as an alternative source of proteins to overcome protein energy malnutrition (PEM) because flour made of

*Address correspondence to this author at the Department of Pharmacy, Faculty of Mathematics and Natural Sciences, Tadulako University, Palu City, Central Sulawesi, Indonesia; Tel: (0451) 422611 extension 365;

E-mail: amelia@untad.ac.id moringa leaves has a protein content three times higher compared to powdered milk. In some tropical countries, moringa has been used as a natural nutrient as it contains vitamins $\mathrm{A}, \mathrm{B}$, and $\mathrm{C}$; calcium; iron; and proteins [5].

Soybeans (Glycine max) are a crop that has been known widely to the public. Most Indonesian society consume soybeans whether in a processed form or in the unprocessed one. The high interest in soybeans among the public is because soybeans are rich in nutrition, especially the vegetable protein content. Wet soybeans contain $286 \mathrm{cal}, 30.2 \mathrm{~g}$ of proteins, $15.6 \mathrm{~g}$ of fats, $30.1 \mathrm{~g}$ of carbohydrates, $196 \mathrm{mg}$ of calcium, 506 $\mathrm{mg}$ of phosphorus, $6.9 \mathrm{~g}$ of iron, $95 \mathrm{SI}$ of vitamin $\mathrm{A}$, and $0.93 \mathrm{mg}$ of vitamin B [3].

Biscuits are one of the foods with which society have been familiar, because they belong to the category of a practical food that can be consumed at any time. Biscuits are also a food product that has been widely developed, one of which includes the addition of substances to improve the nutritional value. The addition of moringa leaf extracts and soybean extracts is expected to increase the nutritional value of biscuits. However, the taste and aroma of moringa leaf 
and soybean extracts may negatively affect consumer acceptance of this biscuit product, making it is necessary to add flavorings in an attempt to deal with this problem. This is why a chocolate flavouring was added to this product as a solution. Chocolate is one of the foods which many people like because it is delicious and also good for the body.

Based on the foregoing, it is important to conduct this research on nutritional formulation and analysis, and the hedonic test of functional biscuits with supplementation of moringa leaves (Moringa oleifera L.) and soybeans (Glycine max (L.) Merill).

\section{EXPERIMENTS}

\subsection{Materials and Methods}

The following were materials and ingredients used in biscuit formulas: wheat flour, refined sugar, margarine, powdered milk, baking powder, eggs, chocolate paste, chocolate chips, plastic packaging, and paper oil. The other materials and substances used were ATK and chemicals for the analysis of protein, carbohydrate, and fat contents.

\subsection{Research Design}

This study employed a completely randomized design (CRD), where each treatment was repeated twice. The formula of basic ingredients was comprised of wheat flour, sugar, eggs, margarine, and baking powder. The following is the composition of each treatment:

$$
\begin{aligned}
\mathrm{P} 1= & \text { basic ingredients without supplementation } \\
\mathrm{P} 2= & \text { basic ingredients + soybean extracts by } 2.5 \% \\
\mathrm{P} 3= & \text { basic ingredients + soybean extracts by } 5 \% \\
\mathrm{P} 4= & \text { basic ingredients + moringa leaf extracts by } \\
& 2.5 \% \\
\mathrm{P} 5= & \text { basic ingredients + moringa leaf extracts by } \\
& 2.5 \%+\text { soybean extracts by } 2.5 \% \\
\mathrm{P} 6= & \text { basic ingredients + moringa leaf extracts by } \\
& 2.5 \%+\text { soybean extracts by } 5 \% \\
\mathrm{P} 7= & \text { basic ingredients }+ \text { moringa leaf extracts by } 5 \% \\
\mathrm{P} 8= & \text { basic ingredients }+ \text { moringa leaf extracts by } 5 \% \\
& + \text { soybean extracts by } 2.5 \% \text { P }=\text { basic } \\
& \text { ingredients }+ \text { moringa leaf extracts by } 5 \%+ \\
& \text { soybean extracts by } 5 \%
\end{aligned}
$$

\subsection{Stages of Study Implementation}

\subsubsection{Preparation of Basic Ingredients}

Wheat flour, chocolate paste, powdered sugar, margarine, eggs, and baking powder were weighed per the basic formula. All the basic ingredients were mixed into a homogeneous dough formula.

\subsubsection{Preparation of Moringa Leaf Extracts}

Freshly-picked moringa leaves were weighed as much as $1 \mathrm{~kg}$, added with $2,000 \mathrm{~mL}$ of water and blended until all the leaves were mashed. Then, filter it using a filter cloth. The filtrate obtained was heated at a temperature of $90^{\circ} \mathrm{C}$ for 10 minutes to allow proteins to coagulate. Moringa leaf extracts that coagulated were separated from the water. The coagulant perpared for a moringa leaf extract in the paste preparation was ready to be used as a supplement in the formulation of biscuits.

\subsubsection{Preparation of Soybean Seed Extracts}

Soybean seeds were weighed as much as $1 \mathrm{~kg}$, then added with $2,000 \mathrm{~mL}$ of water and soaked for 24 hours. Furthermore, the seeds that had been soaked, washed thoroughly, and drained were added with 2,000 $\mathrm{mL}$ of water, then blended until they were completely crushed. Seeds that had been crushed were filtered to obtain a filtrate, heated at a temperature of $90^{\circ} \mathrm{C}$ for 10 minutes to form protein coagulation prepared for soybean extracts were used in the formulation of biscuits.

\subsection{The Formulation of Biscuits "Morisoya"}

The basic ingredient were firstly weighed, which consisted of $275 \mathrm{~g}$ of wheat flour, $125 \mathrm{~g}$ of powdered sugar, $125 \mathrm{~g}$ of margarine, $20 \mathrm{~g}$ of powdered milk, $20 \mathrm{~g}$ of egg, $2 \mathrm{~g}$ of baking powder, and $20 \mathrm{~g}$ of chocolate paste. All the ingredients were mixed until they were homogeneous and afterwards supplements were added to them, depending on the treatment, and then they were kneaded until the formulated dough formula was easy to shape. Furthermore, they were shaped using biscuit molds, placed on an oven dish, and baked in an oven at a temperature of $120^{\circ} \mathrm{C}$ for 10 minutes.

\subsection{Organoleptic Test}

Organoleptic testing is a test that is based on the sensing process. Sensing is defined as a physiopsychological process, which is sensory awareness or recognition of the characteristics of objects due to the stimulation received by the sensory receptors from the 
objects. Sensing can also mean mental reactions (a sensation) when the senses receive stimuli. The reaction or impression that occurs due to stimulation may be an attitude to move towards or go away from, or like or dislike the object gising such stimuli.

This test is also called a hedonic test, as would be done in this study. In this research, an organoleptic test/hedonic test was conducted with a numerical scale ranging from 0 to 5 with a hedonic scale consisting of like it very much, like it much, like it, kinda like it, neutral, and dislike it rated by a total of 20 panelists consisting of students, university students, and housewives. Data from the completed questionnaires were tabulated and analyzed using one-way ANOVA, and were presented in the form of graphics illustrating percentages based on the data on a hedonic scale of 0 to 5 .

\subsection{Data Analysis}

Quantitative data obtained from observation were analyzed using the analysis of variance (ANOVA), especially one-way ANOVA. In the event of significant differences between treatments, it must be followed by Duncan's multiple test.

\section{RESULTS}

\subsection{Hedonic Test Results}

Results of the hedonic test for each treatment can be seen in Figure 1. The formula-based treatments show significant differences in terms of the hedonic test results. The treatment $\mathrm{P} 6$ reaches the highest scale (3.28), followed by the treatment P3 (2.85) that is not significantly different from P5 (2.83), then the treatment P4 (2.65) that is not significantly different from

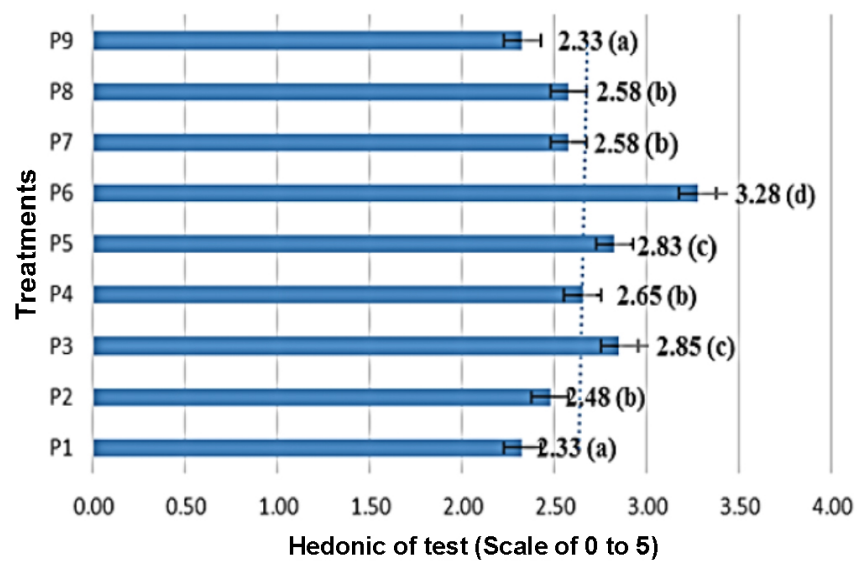

Figure 1: The graph illustrating results of the hedonic test (on a scale of 0 to 5 ) on biscuits "Morisoya" for each treatment. treatments P7 (2.58), P8 (2.58), and P2 (2.48). The treatment with the lowest result is $\mathrm{P} 1$ (2.33), which is not significantly different from P9 (2.33).

The percentages of results for the hedonic test on biscuits "Morisoya" can be seen in Figure 2. The highest percentage is found in the treatment P6 (13\%), followed by treatments P3 (12\%), P5 (12\%), P7 (11\%), and P8 $(11 \%)$. The lowest percentage is seen in treatments P9 $(10 \%)$ and P1 (10\%).

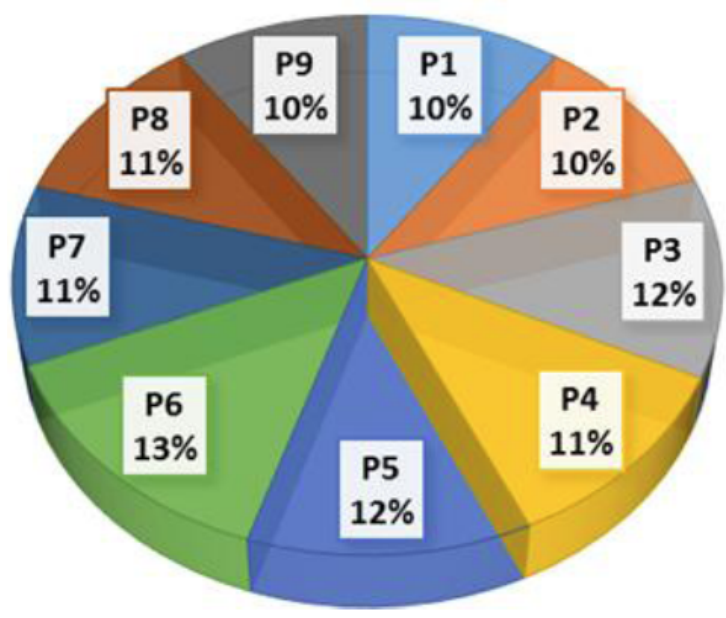

Figure 2: Percentages of results of the hedonic test on biscuits "Morisoya".

\subsection{Protein Content}

Results for the analysis of the protein content of biscuits "Morisoya" for each treatment can be seen in Figure 3. The highest protein content is found in the treatment P8 $(32.50 \%)$, which is not significantly different from those of treatments $\mathrm{P} 9(31.68 \%)$ and $\mathrm{P} 7$ $29.67 \%$ ), followed by treatments P6 $(28.61 \%)$, P5 (2646), P4 (23.78\%), and P2 (18.42\%). The lowest protein content is seen in the treatment $\mathrm{P} 1(13.87 \%)$.

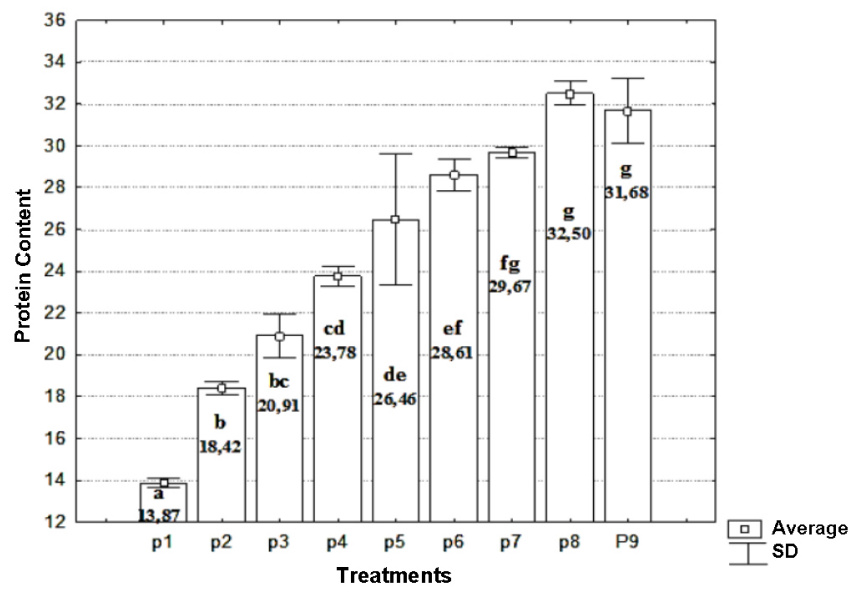

Figure 3: The graph illustrating results for the analysis of the protein content of biscuits "Morisoya" (\%). 


\subsection{Carbohydrate Content}

Results for the analysis of the carbohydrate content of biscuits "Morisoya" for each treatment can be seen in Figure 4. The highest carbohydrate content is seen in treatment $\mathrm{P} 1(62.70 \%)$, followed by treatments $\mathrm{P} 2$ (56.75\%), P3 (51.85\%), P4 (46.44\%), P5 (45.16\%), P7 (41.68\%), P6 (40.05\%), and P8 (39.43\%). The lowest carbohydrate content is seen in the treatment $\mathrm{P} 9$ (36.90\%).

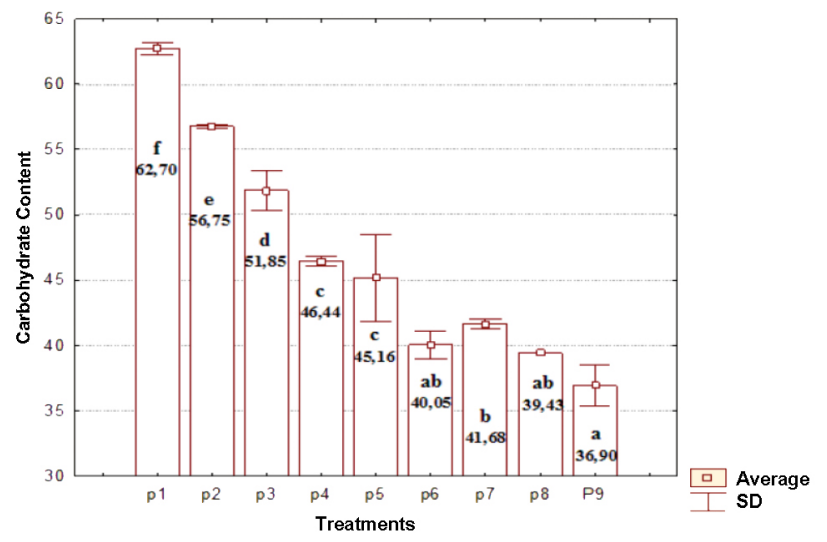

Figure 4: The graph illustrating results for the analysis of the carbohydrate content of biscuits "Morisoya" (\%).

\subsection{Fat Content}

Results for the analysis of the fat content of biscuits "Morisoya" for each treatment can be seen in Figure $\mathbf{5}$. The highest fat content is seen in the treatment P9 (28.92\%), followed by treatments P8 $(25.74 \%), P 7$ (24.41\%), P6 (24.30\%), P5 (21.08\%), P4 (22.76\%), P3 $(20.79 \%)$, and P2 (19.88\%), while the lowest fat content is found in the treatment P1 (17.65\%).

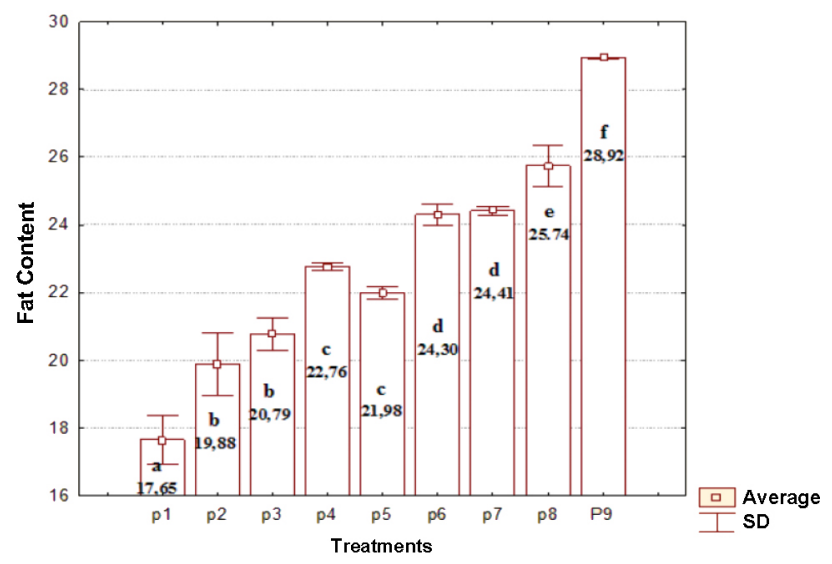

Figure 5: The graph illustrating results for the analysis of the fat content of biscuits "Morisoya" (\%).

\section{DISCUSSION}

Functional foods can be broadly defined as foods that can provide beneficial effects and influence physiological processes, in addition to the effects of the nutrition principally contained in such foods on one's health. The functions that functional foods must have are to serve as a source of nutrition and to have enticing sensory properties [7].

Biscuits are an example of food products that have been well-known across the globe. Biscuits "Morisoya" with supplementation of moringa leaf extracts and soybean extracts contain high protein and fat contents (compared with biscuits without supplementation of such extracts) that can potentially be developed into functional biscuits. Bioactive compounds in moringa cause it to have pharmacological properties [2].

Based on results of the nutritional analysis, an increase in the nutritional content is proportional to an increase in the percentage of extracts added. Whereas based on results of the hedonic test conducted by panelists on the taste of the biscuits, the formula of the treatment $\mathrm{P} 6$ has the highest percentage. $\mathrm{P} 6$ has a formula that is comprised of: basic ingredients, $2.5 \%$ of moringa leaf extracts, and $5 \%$ of soybean extracts, and contains the nutrition proteins, carbohydrates, and fats of $28.61 \%, 40.05 \%$, and $24.30 \%$, respectively. The proteins and fats it contains are higher compared to the control P1 (i.e. $13.87 \%$ and $17.65 \%$ for proteins and fats, respectively). The formulas with a high nutritional content are also indicated by P7, P8, and P9, despite lower hedonic test results compared to those of P6. It may be due to moringa leaves having an unpleasant aroma that is very strong, which can negatively affect the panelists' acceptance [5].

In previous studies on the protein content of moringa leaves, it is revealed that protein concentrate in moringa leaves known as Moringa Protein Concentrate (MPC) has better nutritional quality compared to that of milk protein, both quantitatively and qualitatively. The quality of MPC biscuits is characterized as follows: protein content in the concentrate by $60.48 \%$; protein content in the bicuits by $7.11 \%$; protein digestibility by $80.45 \%$, and PER by 2,291 . Moringa leaf protein concentrate is effective for substituting the components of milk in biscuits for toddlers with PEM (Protein Energy Malnutrition) [5]. In another study, it is also stated that moringa leaves contain proteins nine times higher than yogurt [4].

In addition to containing moringa that is rich in proteins, soybean extracts were also added to those biscuit formulas. In the study conducted by Mishra [8], biscuits with the addition of soy flour have a higher protein content $(40.2 \%)$ compared with biscuits with the 
addition of bran flour (13.5 \%). Soybeans are an excellent source of proteins because they can increase the quantity and quality of the protein content in food products that can be used to meet protein needs in people with malnutrition and can also improve biscuits' texture [6].

Results of the fat analysis on each formula suggest that an increase in the percentage of each formula is proportional to an increase in the moringa leaf and soybean extracts added. This may be influenced by fats contained in soybeans. Soybeans contain unsaturated fats such as linoleic and linolenic acids which are not produced by the body, but they are very good for health maintenance. Soybeans contain $20 \%$ of oil (Shibata, 2008) and soybean oil contains $85 \%$ of unsaturated fatty acids, which are comprised of polyunsatured fatty acids by $61 \%$ and monounsaturated fatty acids by $24 \%$ [8]. Soybeans have been known to contain proteins and fats in high quantities and have a high nutritional value [6].

\section{CONCLUSIONS}

Based on the results, it can be concluded that:

a. The formula of biscuits "Morisoya" which shows the highest hedonic value is the one in the treatment P6 (3.28), that is comprised of basic ingredients, $2.5 \%$ of moringa leaf extracts, and $5 \%$ of soybean extracts, and contains the nutrition proteins, carbohydrates, and fats of $28.61 \%, 40.05 \%$, and $24.30 \%$, respectively.

b. The formula of biscuits "Morisoya" which shows the highest protein content is is the one in the treatment P8 (32.50\%), which was not significantly different from the ones in treatments P9 (31.68\%) and P7 (29.67\%), with a hedonic value of 2.58 (P8), 2.58 (P7), and 2.33 (P8), which is the lowest value.

c. The treatment P6 generates the highest hedonic value while the treatment $P 8$ generates the highest protein content, and both treatments can be developed into functional biscuits with the addition of natural ingredients that can improve the hedonic value with their functional properties.

\section{ACKNOWLEDGMENTS}

The authors would like to thank the Faculty of Mathematics and Natural Sciences of Tadulako University for providing funds allowing this research to be conducted.

\section{REFERENCES}

[1] Amengor MG, Aryeety R, Afari E. Micronutrient Composition and Acceptability of Moringa oleifera leaf-fortified dishes by Children in ADA-East district. J Food Science and Nutrition 2016.

[2] Aminah S. Nutrient Content and Functional Properties of Moringa Plants (Moringa oleifera). Urban Agriculture Bulletin 2015; 5(2): 35-44.

[3] DIY Province DIY. Nutritional Data of Foodstuffs and Processed Products [updated 2016 Sept 27]: Available from: http://bkppp.bantulkab.go.id/filestorage/dokumen/2014/07/Da ta\%20Kandungan\%20Gizi\%20Bahan\%20Pangan\%20dan\%2 0Olahan.pdf

[4] Gopalakrishnan L, Doriya K, Kumar DS. Moringa oleifera: A Review on Nutritive Importance and Its Medicinal Application. Food Science and Human Welness 2016; 5: 49-56. https://doi.org/10.1016/j.fshw.2016.04.001

[5] Kholis N, Hadi F. Toddler Biscuit Bioassay Tests Supplemented with Moringa Folium Extracts (Moringa oleifera) in Malnutrition Rat Models. Journal Agricultural Technology 2010; 11(3): 144-151.

[6] Manley. Technology of Biscuit, Crackers and Cookie. $3^{\text {rd }}$ Ed. Washington 2000.

[7] Marsono Y. Functional Food Development Prospects. Journal Food and Nutrition Technology 2008; 7(1): 19-27.

[8] Mishra N, Chandra R. Development of Functional Biscuit from Soy Flour and Rice Bran. Int $\mathrm{J}$ of Agriculture and Food Science 2012; 2(1): 14-20.

[9] Nugraha A. Bioactivity of Moringa Folium Extracts (Moringa oleifera) on Escherichia coli causes Colibacillosis in Pigs. Udayana University. Denpasar 2013.

[10] Shibata M, Takayama K, Ujiie A, Yamada T, Abe J, Kitamura K. Genetic Relationship Between Lipid Content and Linoleic Acid Concentration in Soybean Seeds. Breeding Science 2008; 58: 361-366.

https://doi.org/10.1270/jsbbs.58.361

[11] Toripah SS, Abidjulu J, Wehantouw F. Antioxidant Activity and Total Phenolic Content of Moringa Folium Extracts (Moringa oleifera). Scientific Pharmacy Journal 2014; 3(4): 37-43. 